\title{
Plasmid Diversity within the Genus Chlamydia
}

\author{
By MERYL LUSHER, CHRISTOPHER C. STOREY \\ AND SHIRLEY J. RICHMOND* \\ Department of Medical Microbiology, Medical School, University of Manchester, Oxford Road, \\ Manchester M13 9PT, UK
}

(Received 3 October 1988; revised 5 December 1988; accepted 17 January 1989)

\begin{abstract}
Examination of 12 Chlamydia psittaci strains recovered from nine different host species (three avian and six mammalian) revealed the presence of a $7.5 \mathrm{~kb}$ plasmid in all isolates except two ovine abortion strains, the human strain IOL207 and the Cal 10 strain. Restriction mapping analysis distinguished four different plasmids that were associated with avian, feline, equine and guinea-pig $C$. psittaci isolates, respectively. The restriction maps of these four C. psittaci plasmid types all differed from that of the plasmid recovered from $C$. trachomatis L2/434. Despite this plasmid diversity, which is likely to be of taxonomic importance, all four plasmids identified within the species $C$. psittaci were found to share some sequence homology, which was mapped to two separate regions in the plasmid molecules. One region, which showed a high degree of homology between $C$. psittaci plasmids and also detectable homology with the $C$. trachomatis plasmid, may represent a common replication control region for plasmids of this genus.
\end{abstract}

\section{INTRODUCTION}

The genus Chlamydia contains two species, Chlamydia trachomatis and Chlamydia psittaci. With the exception of a single murine strain (Nigg, 1942), the species C. trachomatis is exclusively a human pathogen. The two human biovars include 15 serotypes which all contain a cryptic $7.5 \mathrm{~kb}$ plasmid (Palmer \& Falkow, 1986). Restriction mapping of plasmids from these 15 serotypes (Palmer \& Falkow, 1986) and direct DNA sequence analysis of plasmids from serotypes B (Sriprakash \& MacAvoy, 1987), L1 (Hatt et al., 1988) and L2 (Comanducci et al., 1988) have shown this plasmid to be highly conserved within the species $C$. trachomatis.

The species $C$. psittaci on the other hand comprises a diverse group of chlamydial strains which infect a wide range of avian and mammalian hosts. Attempts to recognize subdivisions within this species have been made by plaque neutralization (Schachter et al., 1974), inclusion morphology (Spears \& Storz, 1979), microimmunofluorescence (Perez-Martinez \& Storz, 1985; Wang \& Grayston, 1971), restriction endonuclease analysis of chlamydial chromosomal DNA (McClenaghan et al., 1984; Timms et al., 1988) and monoclonal antibody reactivity (Fukushi et al., 1987). Plasmids have been described in some, but not all, strains of $C$. psittaci; a $6.2 \mathrm{~kb}$ plasmid obtained from a Cal 10 strain was described by Joseph et al. (1986) and McClenaghan et al. (1988) characterized a fragment of plasmid present in all avian isolates they examined. Homology with plasmid DNA from C. trachomatis (Joseph et al., 1986) and other C. psittaci strains (McClenaghan et al., 1988) was reported. However, the latter workers were unable to detect a plasmid in their Cal 10 strain or in either ovine abortion or ovine arthritis isolates. Plasmids also appeared to be absent from TWAR strains described by Campbell et al. (1987).

In the present study cloned $C$. psittaci plasmids from a wide range of avian and mammalian hosts were characterized by restriction mapping and Southern-blot hybridization. Plasmid

Abbreviations: EB, elementary body; LMTA, low-melting-temperature agarose.

$0001-5170$ (C) 1989 SGM 
diversity was demonstrated in C. psittaci recovered from different host sources which may be of taxonomic value both to distinguish avian from mammalian $C$. psittaci and for subgrouping mammalian members of this diverse species.

\section{METHODS}

Chlamydial strains. Chlamydiae studied are listed and their origins referenced in Table 1. N352, one of the two C. psittaci isolates from domestic ducks, contains phage (Richmond et al., 1982) but this was not detected serologically (Bacon et al., 1986) or by DNA hybridization in the other duck strain, 360 (C. C. Storey, unpublished). Strains 6BC, RA1/56, GPIC, Cal 10, IOL207 and L2/434 were kindly donated by, respectively, Dr T. Hatch, University of Tennessee, Memphis, USA; Dr J. Strauss, Institute of Hygiene and Epidemiology, Prague, Czechoslovakia; Dr J. Pearce, University of Birmingham, Birmingham, UK; Dr P. Wyrick, University of North Carolina at Chapel Hill, USA; Professor S. Darougar, Institute of Ophthalmology, London, UK ; and Professor J. Schachter, University of California, San Francisco, USA. Strain N16 is a recent equine isolate obtained by Dr J. Wills, University of Bristol, UK. Dr Wills also supplied the ovine and feline isolates.

Culture and purification of chlamydial elementary bodies. Elementary bodies (EBs) of each strain of Chlamydia were prepared from heavily infected cell monolayers grown in $25 \mathrm{~cm}^{2}$ or $75 \mathrm{~cm}^{2}$ (basal area) plastic flasks in the presence of cycloheximide (Richmond et al., 1985). Strains IOL207 and GPIC were grown in BGM cells; all other chlamydiae were propagated in McCoy cells. EBs were purified by centrifugation through $32 \%$ (v/v) Urografin 370 (Schering Chemicals) (Kuo et al., 1977).

Preparation and cloning of chlamydial plasmid DNA. Plasmid DNA was prepared from purified EBs by the method of Birnboim \& Doly (1979), except that lysozyme treatment was omitted. Plasmid DNA for use as hybridization probes was further purified by electrophoresis through low-melting-temperature agarose (LMTA) gel (Feinberg \& Vogelstein, 1984); otherwise purified plasmid was used directly for cloning. All plasmid DNA preparations were analysed by agarose gel electrophoresis (Maniatis et al., 1982).

Cloned plasmid DNA was prepared by standard techniques (Maniatis et al. 1982). Briefly, plasmid DNA preparations were digested with EcoRI or Ball and ligated to PUC9 plasmid vector DNA that had been cleaved with $E c o$ RI or SmaI and subsequently dephosphorylated (Yanisch-Perron et al., 1985). Ligated DNA was used to transform Escherichia coli JM83 by the method of Kushner (1978). Transformed colonies were screened by colony blot hybridization (Grunstein \& Hogness, 1975) using radiolabelled LMTA-purified native chlamydial plasmid as a probe. Recombinants were amplified in liquid culture prior to DNA isolation and purification by standard alkaline-lysis and $\mathrm{CsCl} /$ ethidium bromide gradient centrifugation (Maniatis et al., 1982).

Restriction endonuclease site mapping. Restriction endonuclease cleavage site maps of cloned plasmid insert DNA were constructed by analysis of the products of single and mixed enzyme digests on agarose electrophoresis gels (Maniatis et al., 1982). All restriction endonuclease and other enzyme incubations were performed under the conditions recommended by the manufacturer (Boehringer Mannheim, Pharmacia or BRL).

Hybridization conditions. Southern transfer and hybridization were carried out as described by Maniatis $e t$ al. (1982). LMTA-purified preparations of native or recombinant chlamydial insert DNA were radiolabelled to a

Table 1. Plasmids identified in the genus Chlamydia

\begin{tabular}{|c|c|c|c|c|}
\hline Host species & Strain & $\begin{array}{l}\text { Plasmid } \\
\text { detected }\end{array}$ & $\begin{array}{c}\text { Plasmid } \\
\text { designation }\end{array}$ & Reference \\
\hline \multicolumn{5}{|l|}{ C. psittaci } \\
\hline Duck & N352 & + & $\mathrm{pCpA1}$ & Richmond et al. (1982) \\
\hline Parakeet & $6 \mathrm{BC}$ & + & $\mathrm{pCpA} 2$ & Morgan \& Wiseman (1946) \\
\hline Duck & 360 & + & pCpA3 & Bacon et al. (1986) \\
\hline Black-headed gull & $\mathrm{RA} 1 / 56$ & + & $\mathrm{pCpA4}$ & Strauss et al. (1957) \\
\hline \multicolumn{5}{|l|}{ Mammalian } \\
\hline Cat & Pring & + & $\mathrm{pCpF1}$ & Wills et al. (1984) \\
\hline Cat & Cello & + & $\mathrm{pCpF} 2$ & Cello (1967) \\
\hline Horse & N16 & + & $\mathrm{pCpE} 1$ & \\
\hline Guinea-pig & GPIC & + & pCpGPl & Murray (1964) \\
\hline Human/ferret & Cal 10 & - & - & Francis \& Magill (1938) \\
\hline Human & IOL207 & - & - & Dwyer et al. (1972) \\
\hline Ovine & A22 & - & - & Stamp et al. (1950) \\
\hline Ovine & S26 & - & - & McClenaghan et al. (1984) \\
\hline \multicolumn{5}{|l|}{ C. trachomatis } \\
\hline Human & $\mathrm{L} 2 / 434$ & + & pCtL2 & Kuo et al. (1977) \\
\hline
\end{tabular}


specific activity of 1-2 $\times 10^{9}$ c.p.m. $\mu \mathrm{g}^{-1}$ by the random-primed oligolabelling procedure of Feinberg \& Vogelstein (1984). DNA that had been transferred to nylon filters (Hybond $\mathrm{N}$; Amersham) was hybridized with radiolabelled probe overnight at $65^{\circ} \mathrm{C}$ then washed twice at $65^{\circ} \mathrm{C}$ in $2 \times \mathrm{SSC}$ (SSC consisted of $0.15 \mathrm{M}-\mathrm{NaCl}$, $0.15 \mathrm{M}$-trisodium citrate, $\mathrm{pH} 7 \cdot 0$ ). Filters were washed in $2 \times \mathrm{SSC}$ and $0.1 \%$ SDS (low-stringency wash) or $0.1 \times$ SSC and $0.1 \%$ SDS (high-stringency wash) at $65{ }^{\circ} \mathrm{C}$, and then exposed overnight to Fuji RX-G film.

\section{RESULTS AND DISCUSSION}

Purified EBs prepared from 12 C. psittaci isolates and the $C$. trachomatis $\mathrm{L} 2$ strain were used to prepare chlamydial plasmid DNA. Faint bands of extrachromosomal DNA were seen following agarose gel electrophoresis of preparations from four avian, two feline, the GPIC strain and an equine isolate of $C$. psittaci, as well as the $C$. trachomatis L2 serotype (data not shown). Because yields of native plasmid DNA were small [approximately $10-100 \mathrm{ng}$ DNA ( $10^{9}$ inclusion-forming units) ${ }^{-1}$, molecular cloning of these plasmids was undertaken to facilitate further analyses. Initial restriction digests of native plasmid DNA showed that all plasmids identified in this study possessed single or multiple EcoRI sites. Accordingly, EcoRI-restricted plasmid DNA was ligated to EcoRI-digested pUC9 vector DNA and used to transform $E$. coli JM83 cells. Recombinant colonies were screened by colony blot hybridization using radiolabelled LMTA-purified plasmid DNA as a probe. Positive clones were used to prepare chlamydial insert DNA.

Digestion of $C$. psittaci plasmids with $E c o$ RI revealed a considerable diversity of plasmids from different host species. Thus, the four avian $C$. psittaci plasmids (pCpA1-4) each yielded recombinant $E c o$ RI fragments of $6 \cdot 2,0.62,0.47$ and $0.2 \mathrm{~kb}$ (Fig. $1 a$, lane 2), while both feline plasmids (pCpF1 and 2) demonstrated a single EcoRI fragment of $7.5 \mathrm{~kb}$ (Fig. 1a, lane 3). The equine plasmid (pCpE1) generated six EcoRI fragments of $4 \cdot 1,1 \cdot 3,1 \cdot 2,0 \cdot 4,0 \cdot 3$ and $0 \cdot 15 \mathrm{~kb}$ (Fig. $1 a$, lane 4) and the guinea-pig plasmid (pCpGP1) was distinguished by four EcoRI fragments of $5,1.5,0.7$ and $0.25 \mathrm{~kb}$ (Fig. $1 a$, lane 5). The EcoRI restriction profile of all four $C$. psittaci plasmid types differed from that obtained from the $C$. trachomatis plasmid clones, which showed EcoRI fragments of $4.5,2.5$ and $0.4 \mathrm{~kb}$ (Fig. $1 a$, lane 6).
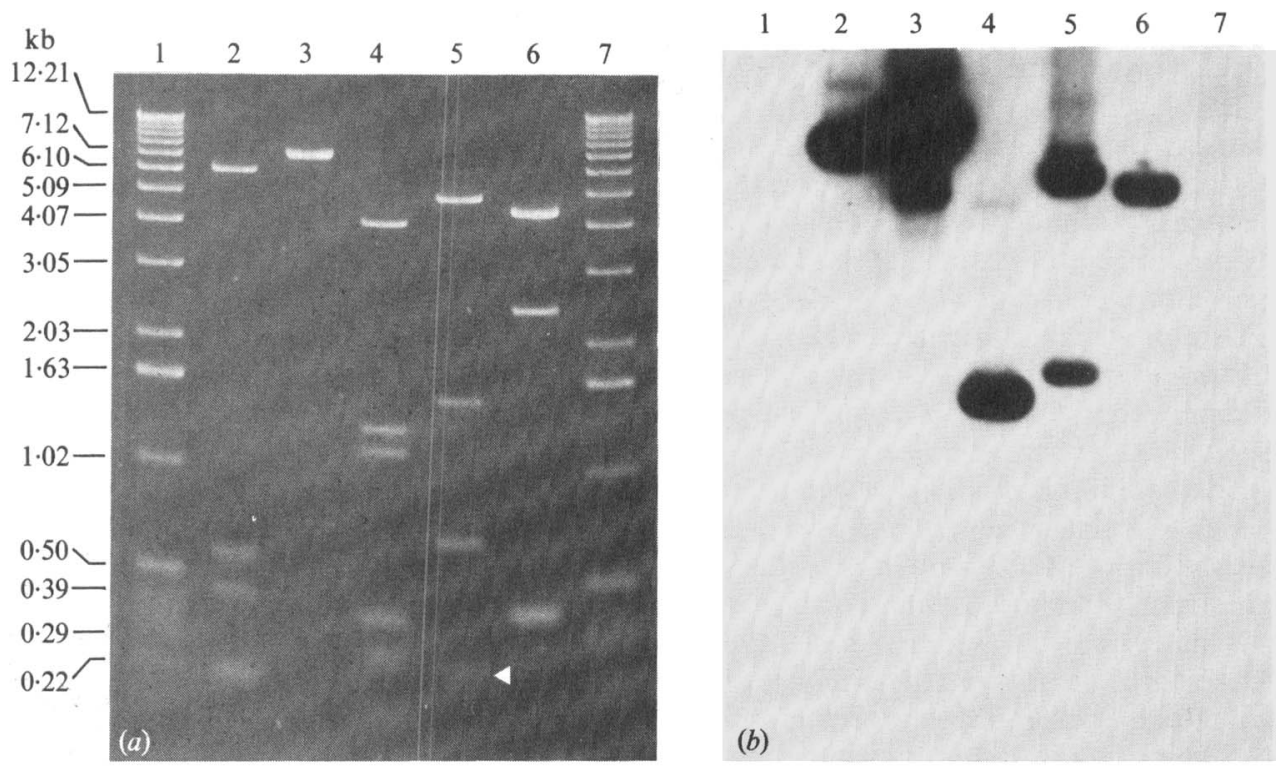

Fig. 1. (a) Ethidium-bromide-stained agarose $(1 \%, \mathrm{w} / \mathrm{v})$ gel electrophoresis and $(b)$ Southern blot hybridization of cloned EcoRI fragments of plasmid DNA loaded in equimolar concentrations. The Southern blot was probed with radiolabelled cloned $7.5 \mathrm{~kb}$ feline plasmid insert DNA and the filter was washed at low stringency. Lanes: $2, \mathrm{pCpA} 1 ; 3, \mathrm{pCpF} 1 ; 4, \mathrm{pCpE} 1 ; 5$, pCpGP1; 6, C. trachomatis L2; 1 and 7 , marker DNA ( $1 \mathrm{~kb}$ ladder; BRL). The arrowhead indicates the position of the $0.25 \mathrm{~kb}$ EcoRI fragment of pCpGP1. 
As restriction endonuclease site mapping of the cloned EcoRI fragments revealed all chlamydial plasmids to have a unique $B a l I$ site, subsequent cloning experiments featured ligation of Ball-linearized plasmids to SmaI-digested pUC9. Recombinant BalI clones and EcoRI-cloned insert DNA were used to prepare restriction endonuclease cleavage maps of the identified plasmids (Fig. 2). Despite the diversity of the characterized plasmids, their overall size was similar (approximately $7.5 \mathrm{~kb}$ ). Our restriction map of the C. trachomatis L2 plasmid showed good agreement with that predicted from the recently published nucleotide sequence of the L2 plasmid (Comanducci et al., 1988).

The four avian $C$. psittaci strains, which include two recent isolates from domestic ducks and two strains isolated more than 30 years ago (Table 1), contained closely related plasmids. Southern blots showed all four cloned EcoRI fragments from the different avian plasmids to cross-hybridize with each other at high stringency. There was no apparent homology, however, between this plasmid and the phage present in N352 (Storey et al., 1988). The $6.2 \mathrm{~kb}$ Eco RI fragments of the four plasmids showed conserved restriction sites for the enzymes HpaII, HaeIII and $X b a \mathrm{I}$ in addition to those shown for pCpAl (Fig. 2). No cleavage of these fragments was obtained with the enzymes ApaI, AvaII, BamHI, BclI, BglI, HpaI, HaeII, KpnI, PstI, PvuI, PvuII, SalI, Sau96I, SmaI, SphI, SstI and Xhol. The restriction map of the $6 \cdot 2 \mathrm{~kb} E c o$ RI fragment of the pCpA plasmids was similar, but not identical, to the $6.2 \mathrm{~kb}$ plasmid from Cal 10 described by Joseph et al. (1986). The $5.6 \mathrm{~kb}$ HindIII fragment of the pCpA plasmids also shared similarities in restriction sites with the $5.9 \mathrm{~kb}$ HindIII fragment of plasmid pAV-1 isolated from a cockatiel strain of $C$. psittaci by McClenaghan et al. (1988), which suggests that these plasmids are related. The latter group of workers also detected pAV-1-related sequences in Southern blots of plasmid DNA from 13 other avian C. psittaci isolates. These observations are consistent with the presence of a common plasmid conserved within avian strains of $C$. psittaci. This plasmid may, therefore, provide a marker which distinguishes avian $C$. psittaci from mammalian strains.

The feline, equine and guinea-pig strains of $C$. psittaci each contained a distinct, hitherto uncharacterized plasmid. The plasmids $\mathrm{pCpF} 1$ and $\mathrm{pCpF} 2$ recovered from the two feline $C$. psittaci strains were found to be highly homologous by Southern blot hybridization analysis of restricted plasmid DNA (data not shown). Both plasmids had identical arrays of sites for the enzymes $E c o$ RV, HaeII, HpaI, HpaII and XmnI in addition to those shown in Fig. 2, while they lacked sites for $A p a \mathrm{I}, A v a \mathrm{II}, B c l \mathrm{I}, B g I \mathrm{I}, K p n \mathrm{I}, M s p \mathrm{I}, N c i \mathrm{I}, P s t \mathrm{I}, P v u \mathrm{I}, S m a \mathrm{I}$ and $X h o \mathrm{I}$. The close similarity of the plasmids isolated from these two feline $C$. psittaci strains [one of which was isolated in the USA (Cello, 1967) and the other in the UK in 1980 (Wills et al., 1984)] suggests that this plasmid is highly conserved within feline $C$. psittaci strains. The three different chlamydial plasmids we have identified in feline, equine and guinea-pig strains of $C$. psittaci may provide useful taxonomic markers for the three distinct mammalian $C$. psittaci strains in which they were found.

Plasmids were not detected in DNA preparations from the four remaining C. psittaci strains analysed by agarose gel electrophoresis or Southern blots probed with the five plasmids characterized in this work. Despite the previous isolation of a plasmid from Cal 10 reported by Joseph et al. (1986), neither we nor other groups (McClenaghan et al., 1988; Dr Ian Clarke, personal communication) have been able to detect plasmids in our respective Cal 10 strains. The absence of a plasmid in the two ovine abortion strains (A22 and S26) is in agreement with the observations of McClenaghan et al. (1988) and the lack of a plasmid in the human C. psittaci isolate IOL207 reinforces the belief in the similarity between this organism and the TWAR strain described by Campbell et al. (1987).

Despite the distinct restriction maps of the four $C$. psittaci plasmids, Southern blots of cloned $E c o$ RI fragments probed reciprocally with each of the plasmids showed that they shared partial DNA homology (Fig. 1b). Additional Southern blot analysis of homologous EcoRI fragments after digestion with appropriate restriction enzymes showed the hybridization to be confined to two separate regions present in each of the identified plasmids (Fig. 2). One region of low sequence homology (approximately 1.5-2.4 kb long) consisted of a cluster of HindIII/XmnI/ $E c o$ RI restriction fragments of plasmid DNA which cross-hybridized under conditions of low stringency (region 1, Fig. 2). A second region, of high homology (which under the high- 

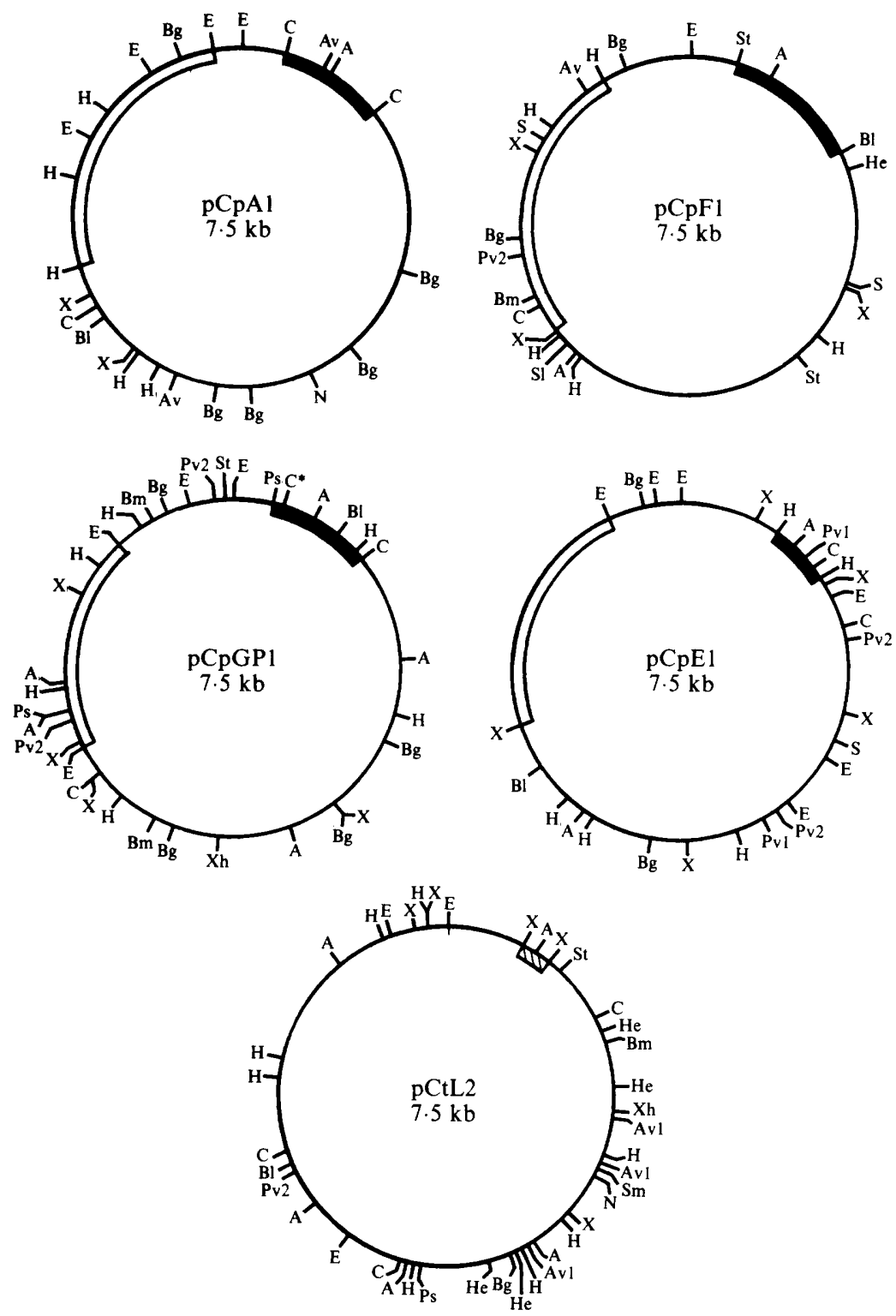

Fig. 2. Restriction endonuclease cleavage maps of four $C$. psittaci plasmid types, pCpA1, $\mathrm{pCpF1}$, pCpGPl and pCpE1, and the C. trachomatis plasmid pCtL2. A, AccI; Av, AvaI; Bl, BalI; B, BamHI; $\mathrm{Bg}, B g I \mathrm{II} ; \mathrm{C}, \mathrm{ClaI}\left(\mathrm{C}^{*}\right.$, dam-methylation-sensitive $C l a \mathrm{I}$ site present in native, but not in recombinant, plasmid); E, EcoRI; He, HaeI; H, HindIII; N, NciI; Ps, PstI; Pv1, PvuI; Pv2, PvuII;Sl, SalI; S, Saw96I; Sm, SmaI; St, SstI; Xh, XhoI; X, XmnI. $\square$, Restriction fragments with low homology between $C$. psittaci plasmids (region 1 ) , restriction fragments with high homology between $C$. psittaci plasmids (region 2); $\mathbb{Z}$, restriction fragment of $C$. trachomatis with low homology with $C$. psittaci plasmids.

stringency conditions used corresponded to a minimum sequence of approximately $200 \mathrm{bp}$ ), was located within a $0.75 \mathrm{~kb} \mathrm{ClaI}$ fragment in the avian plasmid, a $0.7 \mathrm{~kb} P$ st $\mathrm{I} / \mathrm{Cla \textrm {I }}$ fragment in the GPIC plasmid, a $1 \mathrm{~kb}$ Sst I/BalI fragment in the feline plasmid and a $0.45 \mathrm{~kb} H$ indIII fragment in the equine plasmid (region 2, Fig. 2). This region also hybridized under conditions of low

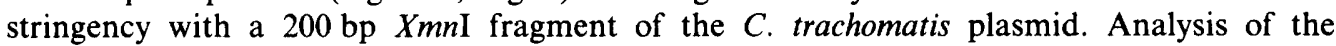
nucleotide sequence of the equivalent $X m n I$ fragment of the $C$. trachomatis L2 plasmid 
determined by Comanducci et al. (1988) revealed that it consisted of an intergenic region of sequence which included the putative origin of replication for the plasmid. This region of the L2 plasmid was characterized by four tandem repeat sequences, 22 bp long, each of which contained a central $A c c I$ site. Our observation that homology region 2 in $C$. psittaci plasmids also contains a conserved $A c c I$ site (Fig. 2) further suggests that this region includes the origins of replication. Despite the plasmid diversity revealed by restriction enzyme analysis in this work, the origin of replication of all Chlamydia plasmids may be similar.

We are grateful to the Kershaw Trust who supported this work.

\section{REFERENCES}

BACON, E. J., Richmond, S. J., WoOd, D. J., STiRling, P., Bevan, B. J. \& Chalmers, W. S. K. (1986). Serological detection of phage infection in Chlamydia psittaci recovered from ducks. Veterinary Record $119,618-620$.

Birnboim, H. C. \& Doly, F. (1979). A rapid alkaline extraction procedure for screening recombinant plasmid DNA. Nucleic Acids Research 7, 1513-1523

Campbell, L. A., Kuo, C. C. \& Grayston, J. T (1987). Characterisation of the new Chlamydic agent, TWAR, as a unique organism by restriction endonuclease analysis and DNA-DNA hybridisation. Journal of Clinical Microbiology 25, 1911-1916.

CELLO, R. M. (1967). Ocular infections in animals with PLT (Bedsonia) group agents. American Journal of Ophthalmology 63, 1270-1273.

Comanducci, M., Riccl, S. \& Ratti, G. (1988). The structure of a plasmid of Chlamydia trachomatis believed to be required for growth within mammalian cells. Molecular Microbiology 2, 531-538.

DWyer, R. ST C., Treharne, J. D., Jones, B. R. \& HERring, J. (1972). Chlamydial infection. Results of microimmunofluorescence tests for the detection of type specific antibody in certain chlamydial infections. British Journal of Venereal Disease 48, 452--458.

Feinberg, A. P. \& Vogelstein, B. (1984). A technique for radiolabelling DNA restriction endonuclease fragments to high specific activity. Analytical Biochemistry 137, 266-267.

Francis, T. \& MaGILL, T. P. (1938). An unidentified virus producing acute meningitis and pneumonia in experimental animals. Journal of Experimental Medicine 68, 147-160.

Fukushi, H., NoJiri, K. \& Hirai, K. (1987). Monoclonal antibody typing of Chlamydia psittaci strains from avian and mammalian species. Journal of Clinical Microbiology 25, 1978-1981.

Grunstein, M. \& Hogness, D. (1975). Colony hybridisation: a method for the isolation of cloned DNAs that contain a specific gene. Proceedings of the National Academy of Sciences of the United States of America 72, 3961-3965.

HatT, C., Ward, M. E. \& Clarke, I. N. (1988). Analysis of the entire nucleotide sequence of the cryptic plasmid of Chlamydia trachomatis serovar L1: evidence for involvement in DNA replication. Nucleic Acids Research 16, 4053-4067.

Joseph, T., Nano, F. E., Garon, C. F. \& Caldwell, H. D. (1986). Molecular characterisation of Chlamydia trachomatis and Chlamydia psittaci plasmids. Infection and Immunity 51, 699-703.
Kuo, C. C., Caldwell, H. D., Wang, S. P. \& Grayston, J. T. (1977). Antigens of Chlamydia trachomatis. In Nongonococcal Urethritis and Related Infections, pp. 176-185. Edited by D. Hobson \& K. K. Holmes. Washington, DC : American Society for Microbiology.

KUSHNER, S. R. (1978). An improved method for transformation of Escherichia coli with Col E1 derived plasmids. In Genetic Engineering, pp. 17-23. Edited by H. B. Boyer \& S. Nicosin. Amsterdam: Elsevier.

Maniatis, T., Fritsch, E. F. \& Sambrook, J. (1982). Molecular Cloning: a Laboratory Manual. Cold Spring Harbor, NY: Cold Spring Harbor Laboratory.

McClenaghan, M., Herring, A. J. \& Aitken, I. D. (1984). Comparison of Chlamydia psittaci isolates by restriction endonuclease analysis. Infection and Immunity 45, 384-389.

McClenaghan, M., Honeycombe, J. R., Bevan, B. J. \& Herring, A. J. (1988). Distribution of plasmid sequences in avian and mammalian strains of Chlamydia psittaci. Journal of General Microbiology 134, 559-565.

Morgan, H. R. \& Wiseman, R. W. (1946). Growth of psittacosis virus in roller tube tissue culture; use in a vaccine. Journal of Infectious Diseases 79, 131133.

Murray, E. S. (1964). Guinea-pig inclusion conjunctivitis virus. 1. Identification as a member of the psittacosis-lymphogranuloma-trachoma group. Journal of Infectious Diseases 114, 1-12.

NigG, C. (1942). Unidentified virus which produces pneumonia and systemic infection in mice. Science 95, 49-50.

Palmer, L. \& Falkow, S. (1986). A common plasmid of the genus Chlamydia trachomatis. Plasmid 16, 5262.

Perez-Martinez, J. A. \& Storz, J. (1985). Antigenic diversity of Chlamydia psittaci of mammalian origin by microimmunofluorescence. Infection and Immunity 50, 905-910.

Richmond, S. J., Stirling, P. \& Ashley, C. R. (1982). Virus infecting the reticulate bodies of an avian strain of Chlamydia psittaci. FEMS Microbiology Letters 14, 31-36.

Richmond, S. J., Bailey, J. M. G., Bailey, A. S. \& MEARns, G. (1985). Primary isolation of Chlamydia trachomatis and Chlamydia psittaci in in vitro cell culture. In Isolation and Identification of Microorganisms of Medical and Veterinary Importance, pp. $297-$ 
312. Edited by C. H. Collins \& J. M. Grange. New York: Academic Press.

Schachter, J., Banks, J., Sugg, N., Storz, J. \& MEYER, K. F. (1974). Serotyping of Chlamydia. I. Isolates of ovine origin. Infection and Immunity 9, 9294.

SPEARS, P. \& Storz, J. (1979). Biotyping of Chlamydia psittaci based on inclusion morphology and response to diethylaminoethyl-dextran (DEAE-D). Infection and Immunity 24, 224-232.

SRIPrakash, K. S. \& MacAvoy, E. S. (1987). Characterisation and sequence of a plasmid from the trachoma biovar of Chlamydia trachomatis. Plasmid 18, 205-214.

Stamp, J. T., McEwen, A. D., Watt, J. A. \& Nisbet, D. J. (1950). Enzootic abortion in ewes. Veterinary Record 62, 251-254.

Storey, C. C., Lusher, M. \& Richmond, S. J. (1988). Characterisation of a bacteriophage recovered from an avian strain of Chlamydia psittaci. In Proceedings of the European Society for Chlamydia Research, p. 94. Bologna, Italy: Societa Editrice Esculapio.
Strauss, J., Bednar, B. \& Sery, V. (1957). The incidence of ornithosis and salmonellosis in the black-headed gull. II. Isolation and identification of ornithosis virus in the gull with simultaneous detection of Salmonella typhimurium. Československá epidemiologie 6, 231-239.

Timms, P., EAves, F. W., Girjes, A. A. \& Lavin, M. F. (1988). Comparison of Chlamydia psittaci isolates by restriction endonuclease and DNA probe analyses. Infection and Immunity 56, 287-290.

Wang, S. P. \& Grayston, J. T. (1971). Classification of trachoma and related strains by microimmunofluorescence. In Trachoma and Related Disorders, pp. 305-321. Edited by R. L. Nichols. Amsterdam: Excerpta Medica.

WILls, J. M., GRUfFydd-Jones, T. J, Richmond, S. J. \& PAUL, I. D. (1984). Isolation of Chlamydia psittaci from cases of conjunctivitis in a colony of cats. Veterinary Record 114, 344-346.

YANISCh-PERRON, C., VieIRA, J. \& MESSING, J. (1985). Improved M13 phage cloning vectors and host strains: nucleotide sequences of the $\mathrm{M} 13 \mathrm{mp} 18$ and pUC19 vectors. Gene 33, 103-119. 